\title{
FONOLOGI \\ (Sejarah Fonologi, Fonetik, Fonemik)
}

\author{
Felta Lafamane \\ feltafamane@gmail.com
}

\begin{abstract}
Abstrak
Fonologi adalah cabang ilmu bahasa (linguistik) yang mengkaji bunyi-bunyi bahasa, proses terbentuknya dan perubahannya. Fonologi mengkaji bunyi bahasa secara umum dan fungsional. Istilah fonem dapat didefinisikan sebagai satuan bahasa terkecil yang bersifat fungsional, artinya satuan fonem memiliki fungsi untuk membedakan makna. Varian fonem berdasarkan posisi dalam kata, misal fonem pertama pada kata makan dan makna secara fonetis berbeda. Variasi suatu fonem yang tidak membedakan arti dinamakan alofon. Kajian fonetik terbagi atas klasifikasi bunyi yang kebanyakan bunyi bahasa Indonesia merupakan bunyi egresif. Dan yang kedua pembentukan vokal, konsonan, diftong, dan kluster. Dalam hal kajian fonetik, perlu adanya fonemisasi yang ditujukan untuk menemukan bunyi-bunyi yang berfungsi dalam rangka pembedaan makna tersebut. Dengan demikian fonemisasi itu bertujuan untuk Menentukan struktur fonemis sebuah bahasa dan Membuat ortografi yang praktis atau ejaan sebuah bahasa. Gejala fonologi Bahasa Indonesia termasuk di dalamnya yaitu penambahan fonem, penghilangan fonem, perubahan fonem, kontraksi, analogi, fonem suprasegmental. Pada tataran kata, tekanan, jangka, dan nada dalam bahasa Indonesia tidak membedakan makna. Namun, pelafalan kata yang menyimpang dalam hal tekanan, dan nada kan terasa janggal.
\end{abstract}

Keyword : fonologi, fonetik, fonemik, bahasa indonesia 


\section{Sejarah Fonologi}

Sejarah fonologi dapat dilacak melalui riwayat pemakaian istilah fonem dari waktu ke waktu. Pada sidang Masyarakat Linguistik Paris, 24 mei 1873, Dufriche Desgenettes mengusulkan nama fonem, sebagai padanan kata Bjm Sprachault. Ferdinand De Saussure dalam bukunya " Memorie Sur Le Systeme Primitif Des Voyelles Dan Les Langues Indo-Europeennes" 'memoir tentang sistem awal vokal bahasa bahasa Indo eropa ' yang terbit pada tahun 1878, mendefinisikan fonem sebagai prototip unik dan hipotetik yang berasal dari bermacam bunyi dalam bahasa -bahasa anggotanya. Sejarah fonologi dalam makalah ini akan lebih mengkhususkan membahas mengenai istilah fonem. Gambaran mengenai perkembangan fonologi dari waktu ke waktu dapat dilihat lewat berbagai aliran dalam fonologi.

\section{a. Aliran Kazan}

Dengan tokohnya Mikolaj Kreszewski, aliran ini mendefinisikan fonem sebagai satuan fonetis tak terbagi yang tidak sama dengan antropofonik yang merupakan kekhasan tiap individu. Tokoh utama aliran kazan adalah Baudoin de Courtenay (1895). Menurut linguis ini, bunyi - bunyi yang secara fonetis berlainan disebut alternan, yang berkerabat secara histiris dan etimologis. Jadi, meskipun dilafalkan berbeda, bunyi - bunyi itu berasal dari satu bentuk yang sama. Pada 1880, Courtenay melancarkan kritiknya terhadap presisi atas beberapa fona yang dianggapnya tidak bermanfaat. Pada 1925, paul passy mempertegas kritik tersebut.

Ferdinand De Saussure. Dalam bukunya "Cours de Linguistique Generale" Kuliah Linguistik umum', Saussure mendefinisikan fonologi sebagai studi tentang bunyi - bunyi bahasa manusia.dari definisi tersebut tercermin bahwa bunyi bahasa yang dimaksud olehnya hanyalah unsure - unsure yang terdengar berbeda oleh telinga dan yang mampu menghasilkan satuan - satuan akustik yang tidak terbatas dalam rangkaian ujaran. Jadi dapat dikatakan bahwa Saussure menggunaklan criteria yang semata - mata fonetis untuk menggambarkan fonem dan memempatkannya hanya pada poros sintagmatik.Lalu Saussure mengoreksinya dan mengatakan bahwa pada sebuah kata yang penting bukanlah bunyi melainkan perbedaan fonisnya yang mampu membedakan kata itu dengan yang lain.

Dengan konsep - konsepnya, meskipun tidak pernah mencantumkan istilah struktur maupun fungsi, Saussure dianggap telah membuka jalan terhadap studi fonologi yang kemudian diadaptasi oleh aliran Praha.

\section{b. Aliran Praha}

Kelahiran fonologi ditandai dengan "Proposition 22" 'Usulan 22' yang diajukan oleh R. Jakobson, S. Karczewski dan N. Trubetzkoy pada konggres Internasional I para linguisdi La Haye, april 1928. Pada 1932 jakobson mendefinisikan fonem sebagai sejumlah ciri fonis yang mampu membedakan bunyi bahasa tertentu dari yang lain, sebagai cara untuk membedakan makna kata. Jadi konsep fonem merupakan sejumlah ciri pembeda (ciri distingtif).

c. Aliran Amerika 
Tokoh aliran ini adalah Edward Sapir (1925). Seorang Enolog dan linguis yang terutama memeliti bahasa - bahasa Indian Amerika. Menurutnya, sistem fonologi bersifat bersifat fungsional. Kiprah Sapir diteruskan oleh penerusnya dari Yale, Leonard Bloomfield, yang karyanya "Language" menjadikan dirinya bapak linguistik Amerika selama 25 tahun. Pada buku itu Bloomfield menjelaskan banyak hal tentang definisi-definisi mutakhir tentang fonem, istilah ciri pembeda, zona penyebaran fonem, kriteria dasar dalam menentukan oposisi fonologis dan lain - lain.

Sifat Behaviouris dan Antimentalis Bloomfield mengantarkannya pada konsepsi tentang komunikasi sebagai perilaku dimana sebuah stimulus (ujaran penutur) memunculkan reaksi mitra tutur. Menurutnya, yang penting dalam bahasa adalah fungsinya untuk menghubungkan stimulus penutur dengan reaksi mitra tutur. Agar fungsi itu terpenuhi, pada tataran bunyi cukuplah kiranya jika setiap fonem berbeda dengan yang lainnya. Sehingga zona penyebaran fonem dan sifat akustiknya bukanlah sesuatu yang penting. Pada tataran fonologi umum, pionir fonologi Amerika lainnya, W.F Twaddell pada 1935 menerbitkan monografi. Di dalamnya Twaddell menegaskan bahwa satuan - satuan fonologis bersifat relasional. Daniel Jones dan Aliran Fonetik Inggris Sejak 1907 Daniel Jones mengajar fonetik di University of London. Setelah itu ia kemudian lebih banyak menggelti praktek fonologi di Inggris. Kegiatannya di jurusan fonetik di University of college lebih difokuskan pada transkripsi fonetis dan pengajaran pelafalan bahasa - bahasa dunia. Perhatiannya pada dua hal itu membuat dirinya memiliki konsep tersendiri tentang fonem. Pada 1919, dalam "Colloquial Sinhalese Reader" yang diterbitkannya bersama H.S Parera, Jones memberikan definisi fonem yang berciri distribusional.

Terinspirasi oleh Baudoin de Courtenay, yang memakai fonem sebagai realitas psikofonetis, Jones menggambarkan fonem sebagai realitas mental. Maksudnya, dalam studi tentang sifat alamiah fonem, kita juga dapat menggunakan baik intuisi, rasa bahasa maupun cara - cara lain yang bersifat psikologis. Hal ini menunjukkan bahwa Jones lebih suka pada sifat fonem, alih - alih fungsinya. Dengan sudut pandang seperti itu sebenarnya Jones sudah memasuki daerah kerja fonologi, dalam analisisnya ia memasukkan data fonologi tertentu, namun dengan menyingkirkan sudutpandangfonologis.

Perkembangan Fonologi Tahun 1960-an sampai 1970-an menandai dimulainya kajian - kajian empiris tentang bahasa Indonesia maupun bahasa - bahasa lain. Contoh karya - karya yang muncul antara lain :

1. Artikel tentang fonologi bahasa jawa dan sistem fonemena dan ejaan (1960) oleh samsuri. Ciri ciri penelitian pada saat itu adalah dipengaruhi oleh gerakan deskriptivisme, menganut aliran neo Bloomfieldian dan bersifat behaviouristik, ketat dalam metodologi dan bahasa lisan menjadi objek utama.

2. Lalu pada tahun 1970an masuk konsep fonem dan wawasan tentang unsur suprasegmental oleh amran halim, dan Hans Lapoliwa dengan fonologi generatifnya. Namun, untuk mengetahui perkembangan mutakhir linguistic Indonesia saat ini diperlukan survey lagi yang lebih mendalam.

\section{Batasan dan Kajian Fonologi}

Istilah fonologi berasal dari bahasa Yunani yaitu phone $=$ 'bunyi', logos = 'ilmu'. Secara harfiah, fonologi adalah ilmu bunyi. Fonologi merupakan bagian dari ilmu bahasa yang mengkaji bunyi. Objek kajian 
fonologi yang pertama bunyi bahasa (fon) yang disebut tata bunyi (fonetik) dan yang kedua mengkaji fonem yang disebut tata fomen (fonemik).

Dengan demikian dapat disimpulkan bahwa fonologi adalah cabang ilmu bahasa (linguistik) yang mengkaji bunyi-bunyi bahasa, proses terbentuknya dan perubahannya. Fonologi mengkaji bunyi bahasa secara umum dan fungsional.

\section{Beberapa Pengetian Mengenai Tata Bunyi}

1. Fonem

Istilah fonem dapat didefinisikan sebagai satuan bahasa terkecil yang bersifat fungsional, artinya satuan fonem memiliki fungsi untuk membedakan makna.

Fonem dalam bahasa mempunyai beberapa macam lafal yang bergantung pada tempatnya dalam kata atau suku kata. Contoh fonem /t/ jika berada di awal kata atau suku kata, dilafalkan secara lepas. Pada kata /topi/, fonem /t/ dilafalkan lepas. Namun jika berada di akhir kata, fonem /t/ tidak diucapkan lepas. Bibir kita masih tetap rapat tertutup saat mengucapkan bunyi, misal pada kata /buat/.

\section{Alofon}

Varian fonem berdasarkan posisi dalam kata, misal fonem pertama pada kata makan dan makna secara fonetis berbeda. Variasi suatu fonem yang tidak membedakan arti dinamakan alofon. Alofon dituliskan diantara dua kurung siku [...]. Kalau[p] yang lepas kita tandai dengan [p] saja, sedangkan [p] yang tak lepas kita tandai dengan [p>]. Maka kita dapat berkata bahwa dalam Bahasa Indonesia fonem /p/ mempunyai dua alofon, yakni [p] dan [p>].

\section{Kajian Fonetik}

1. Klasifikasi Bunyi

a. Berdasarkan ada tidaknya rintangan terhadap arus udara dalam saluran suara.

1. Vokal adalah bunyi bahasa yang arus udaranya tidak mengalami rintangan. Pada pembentukan vokal tidak ada artikulasi.

2. Konsonan adalah bunyi bahasa yang dibentuk dengan menghambat arus udara pada sebagian alat ucap. Dalam hal ini terjadi artikulasi.

3. Bunyi semi-vokal adalah bunyi yang secara praktis termasuk konsonan, tetapi karena pada waktu diartikulasikan belum membentuk konsonan murni.

b. Berdasarkan jalan keluarnya arus udara.

1. Bunyi nasal, yaitu bunyi yang dihasilkan dengan menutup arus udara ke luar melalui rongga mulut dan membuka jalan agar arus udara dapat keluar melalui rongga hidung.

2. Bunyi oral, yaitu bunyi yang dihasilkan dengan jalan mengangkat ujung anak tekak mendekati langit-langit lunak untuk menutupi rongga hidung, sehingga arus udara keluar melalui mulut. 
c. Berdasarkan ada tidaknya ketegangan arus udara saat bunyi di artikulasikan.

1. Bunyi keras (fortis), yaitu bunyi bahasa yang pada waktu di artikulasikan disertai ketegangan kuatarus.

2. Bunyi lunak (lenis), yaitu bunyi yang pada waktu di artikulasikan tidak disertai ketegangan kuatarus.

d. Berdasarkan lamanya bunyi pada waktu diucapkan atau diartikulasikan

1. Bunyi panjang

2. Bunyi pendek

e. Berdasarkan derajat kenyaringannya

Bunyi dibedakan menjadi bunyi nyaring dan bunyi tak nyaring. Derajat kenyaringan ditentukan oleh luas atau besarnya ruang resonansi pada waktu bunyi diucapkan. Makin luas ruang resonansi saluran bicara waktu membentuk bunti, makin tinggi derajat kenyaringannya. Begitu pula sebaliknya.

f. Berdasarkan perwujudannya dalam suku kata

1. Bunyi tunggal, yaitu bunyi yang berdiri sendiri dalam satu suku kata (semua bunyi vokal atau monoftong dan konsonan).

2. Bunyi rangkap, yaitu dua bunyi atau lebih yang terdapat dalam satu suku kata. Bunyi rangkap terdiri dari

3. Diftong (vocal rangkap) : [ai], [au] dan [oi].

4. Klaster (gugus konsonan) : [pr], [kr], [tr] dan [bl].

g. Berdasarkan arus udara

1. Bunyi egresif, yaitu bunyi yang di bentuk dengan cara mengeluarkan arus udara dari dalam paruparu. Bunyi egresif di bedakan menjadi

- Bunyi egresif pulmonik : di bentuk dengan mengecilkan ruang paru-paru,otot perut dan rongga dada.

- Bunyi egresif glotalik : terbentuk dengan cara merapatkan pita suara sehingga glottis dalam keadaan tertutup.

2. Bunyi ingresif, yaitu bunyi yang di bentuk dengan cara menghisap udara ke dalam paru-paru.

- Ingresif glotalik : pembentukannya sama dengan egresif glotalik tetapi berbeda pada arus udara.

- Ingresif velarik : di bentuk dengan menaikkan pangkal lidah di tempatkan pada langit-langit lunak. Kebanyakan bunyi bahasa Indonesia merupakan bunyi egresif.

\section{Pembentukan Vokal, Konsonan, Diftong, dan Kluster}

a. Pembentukan Vokal 
Vokal dibedakan berdasarkan tinggi rendahnya lidah, bagian lidah yang bergerak, bentuk bibir, dan strikturnya. Berikut ini jenis-jenis vokal berdasarkan cara pembentukannya, yakni:

1. Berdasarkan bentuk bibir : vokal bulat, vokal netral, dan vokal tak bulat;

2. Berdasarkan tinggi rendahnya lidah : vokal tinggi, vokal madya (sedang), dan vokal rendah;

3. Berdasarkan bagian lidah yang bergerak : vokal depan, vokal tengah, dan vokal belakang;

4. Berdasarkan strikturnya : vokal tertutup, vokal semi-tertutup, vokal semi-terbuka, dan vokal terbuka.

\section{b. Pembentukan Konsonan}

Pembentukan konsonan didasarkan pada empat faktor, yakni daerah srtikulasi, cara artikulasi, keadaan pita suara, dan jalan keluarnya udara. Berikut ini klasifikasi konsonan tersebut:

1. Berdasarkan daerah artikulasi: konsonan bilabial, labio dental, apikodental, apikoalveolar, palatal, velar, glotal, dan laringal;

2. Berdasarkan cara artikulasi : konsonan hambat, frikatif, getar, lateral, nasal, dan semi-vokal;

3. Berdasarkan keadaan pita suara : konsonan bersuara dan konsonan tak bersuara;

4. Berdasarkan jalan keluarnya udara : konsonan oral dan konsonan nasal.

\section{c. Pembentukan Diftong}

Diftong adalah dua buah vokal yang berdiri bersama dan pada saat diucapkan berubah kualitasnya. Perbedaan vokal dengan diftong adalah terletak pada cara hembusan nafasnya.

Diftong dalam bahasa indonesia adalah sebagai berikut:

1. Diftong /au/, pengucapannya [aw]. Contohnya :

[harimaw] /harimau/

[kerbaw] /kerbau/

2. Diftong /ai/, pengucapannya [ay]. Contohnya :

[santay] /santai/

[sungay] /sungai/

3. Diftong /oi/, pengucapannya [oy]. Contohnya :

[amboy] /amboi/

[asoy] /asoi/

d. Pembentukan Kluster

Gugus atau kluster adalah deretan konsonan yang terdapat bersama pada satu suku kata. 
- Gugus konsonan pertama : /p/,/b/,/t/,/k/,/g/,/s/ dan /d/.

- Gugus konsonan kedua : /l/,/r/ dan /w/.

- Gugus konsonan ketiga :/s/,/m/,/n/ dan /k/.

- Gugus konsonan keduanya adalah konsonan lateral /I/, misalnya :

1. /pl/ [pleno] /pleno/

2. /bl/ [blanko] /blangko/

3. Dan begitu seterusnya hingga konsonan kedua /r/ dan /w/.

- Jika tiga konsonan berderet, maka konsonan pertama selalu /s/, yang kedua /t/,/p/ dan /k/ dan yang ketiga adalah /r/ atau /I/. Contohnya

1. /spr/ [sprey] /sprei

2. /skr/ [skripsi] /skripsi/

3. /skl/ [sklerosis] /sklerosis/

\section{Kajian Fonemik}

Istilah fonem dapat didefinisikan sebagai satuan bahasa terkecil yang bersifat fungsional, artinya satuan fonem memiliki fungsi untuk membedakan makna. Fonem juga dapat dibatasi sebagai unit bunyi yang bersifat distingtif atau unit bunyi yang signifikan.

Dalam hal ini perlu adanya fonemisasi yang ditujukan untuk menemukan bunyi-bunyi yang berfungsi dalam rangka pembedaan makna tersebut. Dengan demikian fonemisasi itu bertujuan untuk

1. Menentukan struktur fonemis sebuah bahasa, dan

2. Membuat ortografi yang praktis atau ejaan sebuah bahasa.

Untuk mengenal dan menentukan bunyi-bunyi bahasa yang bersifat fungsional atau fonem, biasanya dilakukan melalui "kontras pasangan minimal".

Dalam hal ini pasangan minimal ialah pasangan bentuk-bentuk bahasa yang terkecil dan bermakna dalam sebuah bahasa (biasanya berupa kata tunggal) yang secara ideal sama, kecuali satu bunyi berbeda. Sekurang-kurangnya ada empat premis untuk mengenali sebuah fonem, yakni

1. Bunyi bahasa dipengaruhi lingkungannya

2. Bunyi bahasa itu simetris,

3. bunyi bahasa yang secara fonetis mirip, harus digolongkan ke dalam kelas fonem yang berbeda;

4. bunyi bahasa yang bersifat komplementer harus dimasukkan ke dalam kelas fonem yang sama.

\section{Realisasi Fonem}

Realisasi fonem adalah pengungkapan yang sebenarnya dari ciri atau satuan fonologis, yakni fonem menjadi bunyi bahasa. Realisasi fonem erat kaitannya dengan variasi fonem. Variasi fonem merupakan salah satu wujud pengungkapan dari realisasi fonem. Secara segmental fonem bahasa Indonesia dibedakan atas vokal dan konsonan.

2. Variasi Fonem 
Variasi fonem adalah wujud pelbagai manifestasi bersyarat maupun tak bersyarat dari fonem. Wujud variasi suatu fonem yang ditentukan oleh lingkungannya dalam distribusi yang komplementer disebut varian alofonis atau alofon.

F. Gejala Fonologi Bahasa Indonesia

\section{Penambahan Fonem}

Penambahan fonem pada suatu kata pada umumnya berupa penambahan bunyi vokal. Penambahan ini dilakukan untuk kelancaran ucapan.

\section{Penghilangan Fonem}

Penghilangan fonem adalah hilangnya bunyi atau fonem pada awal, tengah dan akhir sebuah kata tanpa mengubah makna. Penghilangan ini biasanya berupa pemendekan kata.

\section{Perubahan Fonem}

Perubahan fonem adalah berubahnya bunyi atau fonem pada sebuah kataagar kata menjadi terdengar dengan jelas atau untuk tujuan tertentu.

\section{Kontraksi}

Kontraksi adalah gejala yang memperlihatkan adanya satu atau lebih fonem yang dihilangkan. Kadangkadang ada perubahan atau penggantian fonem.

\section{Analogi}

Analogi adalah pembentukan suatu kata baru berdasarkan suatu contoh yang sudah ada (Keraf, 1987:133).

\section{Fonem Suprasegmental}

Fonem vokal dan konsonan merupakan fonem segmental karena dapat diruas-ruas. Fonem tersebut biasanya terwujud bersama-sama dengan ciri suprasegmentalseperti tekanan, jangka dan nada. Disamping ketiga ciri itu, pada untaian terdengar pula ciri suprasegmental lain, yakni intonasi dan ritme.

- Jangka, yaitu panjang pendeknya bunyi yang di ucapkan. Tanda [...]

- Tekanan, yaitu penonjolan suku kata dengan memperpanjang pengucapan, meninggikan nada dan memperbesar intensitas tenaga dalam pengucapan suku kata tersebut.

- Jeda atau sendi, yaitu cirri berhentinya pengucapan bunyi

- Intonasi, adalah cirri suprasegmental yang berhubungan dengan naik turunnya nada dalam pelafalan kalimat.

- Ritme, adalah ciri suprasegmental yang berhubungan dengan pola pemberian tekanan pada kata dalam kalimat. 
Pada tataran kata, tekanan, jangka, dan nada dalam bahasa Indonesia tidak membedakan makna. Namun, pelafalan kata yang menyimpang dalam hal tekanan, dan nada kan terasa janggal.

Jenis-jenis perubahan fonem bunyi tersebut berupa asimilasi, disimilasi, modifikasi vokal, netralisasi, zeroisasi, metatesis, diftongisasi, monoftongisasi, dan anaptiksis, sebagaimana uraian berikut.

a) Asimilasi

Asimilasi adalah perubahan bunyi dari dua hal bunyi yang tidak sama menjadi bunyi yang sama atau hampir sama. Hal ini terjadi karena bunyi-bunyi bahasa itu diucapkan secara berurutan sehingga berpotensi untuk saling mempengaruhi atau dipengaruhi.

Dalam bahasa Indonesia, asimilasi fonetis terjadi pada bunyi nasal pada kata tentang dan tendang. Bunyi nasal pada tentangdiucapkan apiko-dental karena bunyi yang mengikutinya, yaitu [t], juga apiko-dental. Bunyi nasal pada tendang diucapkan apiko-alveolar karena bunyi yang mengikutinya, yaitu [d], juga apiko-alveolar. Perubahan bunyi nasal tersebut masih dalam lingkup alofon dari fonem yang sama.

b) Disimilasi

Disimilasi adalah perubahan bunyi dari dua bunyi yang sama atau mirip menjadi bunyi yang tidak sama atau berbeda. Contoh :

Kata bahasa Indonesia belajar [bəlajar] berasal dari penggabungan prefix ber [bər] dan bentuk dasar ajar [ajar]. Mestinya, kalau tidak ada perubahan menjadi berajar [bərajar]. Tetapi, karena ada dua bunyi [r], maka [ $r$ ] yang pertama diperbedakan atau didisimilasikan menjadi [l] sehingga menjadi [bəlajar]. Karena perubahan tersebut sudah menembus batas fonem, yaitu [r] merupakan alofon dari fonem / $r /$ dan [l] merupakan alofon dari fonem ///, maka disebut disimilasi fonemis.

c) Modifikasi vokal

Modifikasi vokal adalah perubahan bunyi vokal sebagai akibat dari pengaruh bunyi lain yang mengikutinya. Perubahan ini sebenarnya bisa dimasukkan kedalam peristiwa asimilasi, tetapi karena kasus ini tergolong khas, maka perlu disendirikan.

d) Netralisasi

Netralisasi adalah perubahan bunyi fonemis sebagai akibat pengaruh lingkungan. Untk mejelaskann kasus ini bisa dicermati ilustrasi berikut. Dengan cara pasangan minimal [baran] 'barang'-[parang] 'paran' bisa disimpulkan bahwa dalam bahasa Indonesia ada fonem /b/ dan /p/.Tetapi dalam kondisi tertentu, fungsi pembeda antara /b/ dan /p/ bisa batal setidak-tidaknya bermasalah karena dijumpai yang sama. Minsalnya, fonem /b/ pada silaba akhir pada kata adab dan sebab diucapkan [p']: [adap] dan [sabab'], yang persis sama dengan pengucapan fonem /p/ pada atap dan usap: [atap'] dan [usap']. Mengapa terjadi demikian? Karena konsonan hambatan letup bersuara [b] tidak mungkin terjadi pada posisi koda. Ketika dinetralisasikan menjadi hambatan tidak bersuara, yaitu [p'], sama dengan realisasi yang biasa terdapat dalam fonem /p/. 


\section{e) Zeroisasi}

Zeroisasi adalah penghilangan bunyi fonemis sebagai akibat upaya penghematan atau ekonomisasi pengucapan. Peristiwa ini biasa terjadi pada penuturan bahasa-bahasa di dunia, termasuk bahasa Indonesia, asal saja tidak menggangu proses dan tujuan komunikasi. Peristiwa ini terus dikembangkan karena secara diam-diam telah didukung dan disepakti oleh komunitas penuturnya.

Dalam bahasa Indonesia sering dijumpai pemakaian katatak ataundak untuk tidak, tiada untuk tidak ada, gimana untuk bagaimana, tapi untuk tetapi. Padahal, penghilangan beberapa fonem tersebut dianggap tidak baku oleh tatabahasa baku bahasa Indonesia. Tetapi, karena demi kemudahan dan kehematan, gejala itu terus berlangsung. Zeroisasi dengan model penyingkatan ini biasa disebut kontraksi. Apabila diklasifikasikan, zeroisasi ini paling tidak ada tiga jenis, yaitu : aferesis, apokop, dan sinkop.

f) Metatesis

Metatesis adalah perubahan urutan bunyi fonemis pada suatu kata sehingga menjadi dua bentuk kata yang bersaing. Dalam bahasa Indonesia, kata-kata yang mengalami metatesis ini tidak banyak.

g) Diftongisasi

Diftongisasi adalah perubahan bunyi vokal tunggal (monoftong) menjadi dua bunyi vokal atau vokal rangkap (diftong) secara berurutan. Perubahan dari vokal tunggal ke vokal rangkap ini masih diucapkan dalam satu puncak kenyaringan sehingga tetap dalam satu silaba.

h) Monoftongisasi

Monoftongisasi yaitu perubahan dua bunyi vokal atau vokal rangkap (diftong) menjadi vokal (monoftong). (Muslich 2012 : 126). Peristiwa penunggalan vokal ini banyak terjadi dalam bahasa Indonesia sebagai sikap pemudahan pengucapan terhadap bunyi-bunyi diftong.

Monoftongisasi adalah proses perubahan dua buah vokal atau gugus vokal menjadi sebuah vokal. Poses ini banyak terjadi dalam bahasa Indonesia akibat dari ingin memudahkan ucapan. (Chaer 2009 : 104).

Monoftongisasi adalah proses perubahan bentuk kata yang berujud sebuah diftong berubah menjadi sebuah monoftong. Jadi, monoftongisasi adalah proses perubahan dua bunyi vokal menjadi sebuah vokal.

Contoh:

Ramai menjadi (rame)

Kalao menjadi (kalo)

Danau menjadi (danau)

Satai menjadi (sate) 
Damai menjadi (dame)

Sungai menjadi (sunge)

i) Anaptiksis

Anaptiksis atau suara bakti adalah perubahan bunyi dengan jalan menambahkan bunyi vokal tertentu di antara dua konsonan untuk memperlancar ucapan. Bunyi yang biasa ditambahkan adalah bunyi vokal lemah. Dalam bahasa Indonesia, penambahan bunyi vokal lemah ini biasa terdapat dalam kluster. (Muslich 2012 : 126).

Anaptiksis adalah proses penambahan bunyi vokal di antara dua konsoan dalam sebuah kata; atau penambahan sebuah konsonan pada sebuah kata tertentu. (Chaer 2009 : 105).

Anaptiksis (suara bakti) adalah proses perubahan bentuk kata yang berujud penambahan satu bunyi antara dua fonem dalam sebuah kata guna melancarkan ucapan.

Jadi, anaptikis adalah perubahan bentuk kata dengan menambahkan bunyi vokal tertentu di antara dua konsonan.

Contoh:

Putra menjadi putera

Putri menjadi puteri

Bahtra menjadi bahtera

Srigala menjadi serigala

Sloka menjadi seloka

Anaptikis ada tiga yaitu:

Protesis adalah proses penambhan bunyi ada awal kata. Misalnya:

Mas menjadi emas

Mpu menjadi empu

Tik menjadi ketik

Lang menjadi elang

Epentesis adalah proses penambahan bunyi pada tengah kata. Misalnya:

Kapak menjadi kampak

Sajak menjadi sanjak 
Upama menjadi umpama

Beteng menjadi benteng

Paragog adalah proses penambahan bunyi pada posisi akhir kata. Misalnya:

Huubala menjadi hulubalang

\section{Penutup}

Fonologi adalah cabang ilmu bahasa (linguistik) yang mengkaji bunyi-bunyi bahasa, proses terbentuknya dan perubahannya. Fonologi mengkaji bunyi bahasa secara umum dan fungsional.

Istilah fonem dapat didefinisikan sebagai satuan bahasa terkecil yang bersifat fungsional, artinya satuan fonem memiliki fungsi untuk membedakan makna. Varian fonem berdasarkan posisi dalam kata, misal fonem pertama pada kata makan dan makna secara fonetis berbeda. Variasi suatu fonem yang tidak membedakan arti dinamakan alofon.

Kajian fonetik terbagi atas klasifikasi bunyi yang kebanyakan bunyi bahasa Indonesia merupakan bunyi egresif. Dan yang kedua pembentukan vokal, konsonan, diftong, dan kluster.

Dalam hal kajian fonetik, perlu adanya fonemisasi yang ditujukan untuk menemukan bunyi-bunyi yang berfungsi dalam rangka pembedaan makna tersebut. Dengan demikian fonemisasi itu bertujuan untuk

1.) Menentukan struktur fonemis sebuah bahasa, dan

2.) Membuat ortografi yang praktis atau ejaan sebuah bahasa.

Gejala fonologi Bahasa Indonesia termasuk di dalamnya yaitu penambahan fonem, penghilangan fonem, perubahan fonem, kontraksi, analogi, fonem suprasegmental. Pada tataran kata, tekanan, jangka, dan nada dalam bahasa Indonesia tidak membedakan makna. Namun, pelafalan kata yang menyimpang dalam hal tekanan, dan nada kan terasa janggal.

\section{DAFTAR PUSTAKA}

Chaer, Abdul. 1994. Linguistik Umum. Jakarta: Rineka Cipta

Widodo. 2004. Fonologi Bahasa Jawa. Semarang

Alwi, Hasan (Peny.) 1993. Tata Bahasa Baku Bahasa Indonesia. Jakarta: Balai Pustaka.

Kridalaksana, Harimurti, 1982. Kamus Linguistik. Jakarta: PT Gramedia.

Lass, Roger. 1988. Fonologi (Terj.) Warsono. Cambridg 
Amanto, B. S., Umanailo, M. C. B., Wulandari, R. S., Taufik, T., \& Susiati, S. (2019). Local Consumption Diversification. Int. J. Sci. Technol. Res, 8(8), 1865-1869.

Amri, M., Tahir, S. Z. A. B., \& Ahmad, S. (2017). The Implementation of Islamic Teaching in Multiculturalism Society: A Case Study at Pesantren Schools in Indonesia. Asian Social Science, 13(6), 125.

Andini, K. NILAI BUDAYA SUKU BAJO SAMPELA DALAM FILM THE MIRROR NEVER LIES KARYA KAMILA ANDINI.

ARYANA, A. PERBANDINGAN GAYA BAHASA DALAM NOVEL ATHEIS KARYA ACHDIAT KARTA MIHARDJA DAN NOVEL TELEGRAM KARYA PUTU WIJAYA: TINJAUAN STILISTIKA.

Azwan, A. (2018). Politeness strategies of refusals to requests by Ambonese community. LINGUA: Jurnal Bahasa, Sastra, Dan Pengajarannya, 15(1), 1-6.

Bin-Tahir, S. Z., Atmowardoyo, H., Dollah, S., Rinantanti, Y., \& Suriaman, A. (2018). MULTILINGUAL AND MONO-MULTILINGUAL STUDENTS'PERFORMANCE IN ENGLISH SPEAKING. Journal of Advanced English Studies, 1(2), 32-38.

Bin Tahir, S. Z. (2017). Multilingual teaching and learning at Pesantren Schools in Indonesia. Asian EFL Journal, 89, 74-94.

Bin Tahir, S. Z. (2015). The attitude of Santri and Ustadz toward multilingual education at Pesantren. International Journal of Language and Linguistics, 3(4), 210-216.

Bin-Tahir, S. Z., \& Rinantanti, Y. (2016). Multilingual lecturers' competence in english teaching at the university of Iqra Buru, Indonesia. Asian EFL Journal, 5, 79-92.

Bin-Tahir, S. Z., Saidah, U., Mufidah, N., \& Bugis, R. (2018). The impact of translanguaging approach on teaching Arabic reading in a multilingual classroom. Ijaz Arabi Journal of Arabic Learning, 1(1).

Bin-Tahir, S. Z., Bugis, R., \& Tasiana, R. (2017). Intercultural Communication of a Multicultural Family in Buru Regency. Lingual: Journal of Language and Culture, 9(2), 8.

Djamudi, N. L., Nurlaela, M., Nazar, A., Nuryadin, C., Musywirah, I., \& Sari, H. (2019, October). Alternative social environment policy through educational values in Kafi'a's customary speech to the kaledupa community of Wakatobi Island, Indonesia. In IOP Conference Series: Earth and Environmental Science (Vol. 343, No. 1, p. 012118). IOP Publishing.

Djunaidi, F. G., Azwan, A. Y. T., Iye, R., \& bin Tahir, S. Z. Decks Range Gola Village Community Begun District Buton District North.

Indonesia, K. K. D. B. Morfologi Bahasa Indonesia. 
Iye, R., \& Susiati, S. (2018). NILAI EDUKATIF DALAM NOVEL SEBAIT CINTA DI BAWAH LANGIT KAIRO KARYA MAHMUD JAUHARI ALI (Educative Values in Sebait Cinta di Bawah Langit Kairo by Mahmud Jauhari Ali). Sirok Bastra, 6(2), 185-191.

Iye, R. (2018). Tuturan emosi mahasiswa kota baubau dalam ranah demonstrasi.

Iye, R., Susiati, S., \& Karim, K. (2020). Citra Perempuan dalam Iklan Sabun Shinzui. Sang Pencerah: Jurnal IImiah Universitas Muhammadiyah Buton, 6(1), 1-7.

Iye, R. (2018). Tuturan dalam Prosesi Lamaran Pernikahan di Tomia Kabupaten Wakatobi. Jurnal Totobuang, 6(2).

Iye, R. H. NILAI-NILAI MORAL DALAM TOKOH UTAMA PADA NOVEL SATIN MERAH KARYA BRAHMANTO ANINDITO DAN RIE YANTI. TELAGA BAHASA,(7), 2, 195-206.

Iye, R. WRITING SKILLS IN SMP USWATUN HASANAH, BURU DISTRICT.

Iye, R. JI Prof Dr HAR Basalamah No, and Namlea-Kab Buru.". TUTURAN DALAM PROSESI LAMARAN PERNIKAHAN DI TOMIA KABUPATEN WAKATOBI." Kontemporer. Bandung: PT Remaja.

Karim, K., Maknun, T., \& Abbas, A. (2019). Praanggapan Dalam Pamflet Sosialisasi Pelestarian Lingkungan Di Kabupaten Wakatobi. Jurnal Ilmu Budaya, 7(2), 241-247.

Mansyur, F. A., \& Suherman, L. A. (2020). The Function of Proverbs as Educational Media: Anthropological Linguistics on Wolio Proverbs. ELS Journal on Interdisciplinary Studies in Humanities, $3(2), 271-286$.

Rahayaan, I., Azwan, A., \& Bugis, R. (2016). The Students' Writing Ability through Cooperative Script Method. Jurnal Retemena, 2(2).

Sadat, A., Nazar, A., Suherman, L. O. A., Alzarliani, W. O. D., \& Birawida, A. B. (2019, October). Environmental care behavior through e-jas model with science edutainment approach. In IOP Conference Series: Earth and Environmental Science (Vol. 343, No. 1, p. 012126). IOP Publishing.

Sadat, A., Sa'ban, L. M. A., Suherman, L. O. A., Bahari, S., Ibrahim, T., \& Zainal, M. (2019, October). Internalization characters of environmental care and disaster response through care partner schools. In IOP Conference Series: Earth and Environmental Science (Vol. 343, No. 1, p. 012125). IOP Publishing.

Salamun, T. (2018). DEIKSIS PERSONA BAHASA INDONESIA DIALEK AMBON [Personal Deixes of Indonesian Leanguage With Ambonese Dialect]. Totobuang, 5, 325-339.

Salamun, T. (2018). RELASI KEKERABATAN BAHASA HITU, WAKAL, MORELA, MAMALA, DAN HILA DI PROVINSI MALUKU [The Family Relationship Language Hitu, Wakal, Morela, Mamala, and Hila in Maluku Province].

Suherman, L. A. (2018). The Analysis of Metaphorical Domain on English "Stab Verb" in Corpora. ELS Journal on Interdisciplinary Studies in Humanities, 1(1), 52-58. 
Suherman, L. O. A., Salam, S., Mursanto, D., Efendi, A., Bahar, S. B., \& Kanna, T. (2019, October). The effect of open-air curing on compressive strength of geopolymer mortar containing laterite soil and slaked lime. In IOP Conference Series: Earth and Environmental Science (Vol. 343, No. 1, p. 012133). IOP Publishing.

Susiati, S., \& lye, R. (2018). Kajian Geografi Bahasa dan Dialek di Sulawesi Tenggara: Analisis Dialektometri. Gramatika: Jurnal IImiah Kebahasaan dan Kesastraan, 6(2), 137-151.

Susiati, S., Iye, R., \& Suherman, L. O. A. (2019). Hot Potatoes Multimedia Applications in Evaluation of Indonesian Learning In SMP Students in Buru District. ELS Journal on Interdisciplinary Studies in Humanities, 2(4), 556-570.

Susiati, S. (2018). Homonim bahasa kepulauan tukang besi dialek kaledupa di kabupaten wakatobi [the homonymon of tukang besi island languange in kaledupa dialect at wakatobi regency]. Totobuang, 6 (1), 109, 123.

Susiati, S. (2020). Emosi Verbal Suku Bajo Sampela.

Susiati, S. (2020). Fenomena Tuturan Emosi Verbal Bahasa Indonesia Suku Bajo Sampela.

Susiati, S. (2020). Nilai Budaya Suku Bajo Sampela Dalam Film The Mirror Never Lies Karya Kamila Andini.

Susiati, S. (2020). Konsep Pertentangan Dalam Film" Aisyah Biarkan Kami Bersaudara" Karya Herwin Novianto.

Susiati, S. (2020). Strategi AMBT untuk Meningkatkan Kemampuan Membaca Pemahaman Interpretatif Siswa Kelas IV SD Negeri 3 Namlea Kabupaten Buru.

Susiati, S. (2020). Fungsi Konatif Pada Iklan Mesin Cuci Hole-Less Tub Dari Sharp: Analisis Wacana Kritis.

Susiati, S. (2020). GAYA BAHASA SECARA UMUM DAN GAYA BAHASA PEMBUNGKUS PIKIRAN.

Susiati, S. (2020). The Concept Of Togetherness In The Films" Aisyah Biarkan Kami Bersaudara" By Herwin Novianto.

Susiati, S. (2020). Konsep Kebersamaan Dalam Film" Aisyah Biarkan Kami Bersaudara" Karya Herwin Novianto.

Susiati, S. (2020). Teori dan Aliran Linguistik: Tata Bahasa Generatif.

Susiati, S. (2020). Metode Pembelajaran Bahasa Indonesia: Sosiodrama.

Susiati, S. (2020). Rekontruksi Internal Bahasa Bugis dan Bahasa Makassar: Linguistik Komparatif.

Susiati, S. Bahan Ajar: Psikolinguistik.

Susiati, S. (2020). PENTINGNYA MELESTARIKAN BAHASA DAERAH. 
Susiati, S. (2020). Morfologi Kelas Kata Dalam Bahasa Indonesia.

Susiati, S. (2020). Semantik: Teori Semantik, Relasi Makna, Marked, Dan Unmarked.

Susiati, Y. T. Risman Iye. A. Kesantunan Imperatif Bahasa Indonesia Suku Bajo Sampela: Balai Pembinaan dan Pengembangan Bahasa. 2018. Kongres Bahasa Indonesia (No. 12, pp. 1-6). Report.

Susiati, S. (2020). Kesantunan Imperatif Bahasa Melayu Ambon.

Susiati, S. (2020). Gaya Bahasa Secara Umum Dan Gaya Bahasa Pembungkus Pikiran: Stilistika.

Susiati, S. (2020). Tuturan Kesantunan Imperatif Bahasa Indonesia Suku Bajo Sampela.

Susiati, S. (2020). Nilai Budaya Suku Bajo Sampela Dalam Film The Mirror Never Lies Karya Kamila Andini.

Susiati, S. (2020). Pengaplikasian Multimedia Hot Potatoes Dalam Evaluasi Pembelajaran Bahasa Indonesia Pada Siswa SMP Negeri 9 Buru.

Susiati, S., \& lye, R. (2018). Kajian Geografi Bahasa dan Dialek di Sulawesi Tenggara: Analisis Dialektometri. Gramatika: Jurnal IImiah Kebahasaan dan Kesastraan. 6 (2), 137-151.

Susiati, S. (2020). Kaidah Fonologi Bahasa Indonesia.

Susiati, S. (2020). Wujud Morfologi Bahasa Indonesia.

Susiati, S. (2020). Makian Bahasa Wakatobi Dialek Kaledupa.

Susiati, S. (2020). Eksistensi Manusia Dalam Film" Aisyah Biarkan Kami Bersaudara" Karya Herwin Novianto.

SUsiati, S. NILAI BUDAYA SUKU BAJO SAMPELA DALAM FILM THE MIRROR NEVER LIES.

Susiati, S. (2020). Konsep Keterasingan Dalam Film" Aisyah Biarkan Kami Bersaudara" Karya Herwin Novianto.

Susiati, S. (2020). Concept Of Conflict In The Films "AISYAH BIARKAN KAMI BERSAUDARA" By Herwin Novianto.

Susiati, S. (2020). Embrio Nasionalisme Dalam Bahasa dan Sastra.

Susiati, S. PERWUJUDAN SIMILE OLEH MERARI SIREGAR DALAM NOVEL AZAB DAN SENGSARA.

Susiati, S. (2020). Nilai Pembentuk Karakter Masyarakat Wakatobi Melalui Kabhanti Wa Leja.

Tahir, S. Z. A. B. (2017). Pengembangan Materi Multibahasa untuk Siswa Pesantren. Unpublish dissertation.

Tahir, S. Z. B. (2015). Multilingual Teaching And Learning At Pesantren. 14 Asian EFL Journal Conference. 
Tenriawali, A. Y. (2018). Representasi korban kekerasan dalam teks berita daring tribun timur: analisis wacana kritis [the representation victims of violence in tribun timur online news text: critical discourse analysis]. TOTOBUANG, 6 (1), 1, 15.

Yusdianti, A. (2020). THE REPRESENTATION VICTIMS OF VIOLENCE IN TRIBUN TIMUR ONLINE NEWS TEXT: CRITICAL DISCOURSE ANALYSIS. 